\title{
Production of Metallurgical Coke Utilizing Low-Rank Coals Upgraded by Mild Solvent Treatment
}

\author{
Ryuichi ASHIDA, ${ }^{1 * *}$ Kazumi IWASE ${ }^{1)}$ and Kouichi MIURA ${ }^{21}$ \\ 1) Department of Chemical Engineering, Kyoto University, Kyoto-daigaku Katsura, Nishikyo-ku, Kyoto, 615-8510 Japan. \\ 2) Institute of Advanced Energy, Kyoto University, Gokasho, Uji, Kyoto, 611-0011 Japan.
}

(Received on May 16, 2016; accepted on September 1, 2016; J-STAGE Advance published date: November 24, 2016)

\begin{abstract}
Steel industries need to increase the use of low-rank coals in coke making since coking coals have been depleting and the price of coking coal has been increasing. In this study we propose to pretreat low-rank coals in non-polar solvent such as 1-methylnaphthalene below $400^{\circ} \mathrm{C}$ for converting them to a substitute for coking coals. The proposed method was found to be effective in deoxygenating low-rank coals significantly while suppressing cross-linking or polymerization reactions which often accompany deoxygenation reactions. The amount of low-molecular-weight compounds formed in the solvent-treated coals was comparable to that existing in coking coals. Coking tests utilizing the solvent-treated coals suggested that the solvent-treated coals can be substitutes for slightly-coking coals in coke making process.
\end{abstract}

KEY WORDS: low-rank coals; metallurgical coke; solvent treatment; upgrading.

\section{Introduction}

Steel industries need to increase the use of low-rank coals in coke making since coking coals have been depleting and the price of coking coal has been increasing. In order to produce cokes with mechanical strength using conventional coke ovens, it is necessary that coals have thermal plasticity. It is believed that the thermal plasticity of coals is associated with the amount of inherent low-molecular-weight compounds, $\gamma$ compounds, ${ }^{1-3)}$ and the amount of low-molecularweight compounds formed during pyrolysis, metaplast. ${ }^{4-6)}$ Since coking coals generally have a sufficient amount of such low-molecular-weight compounds, they show thermal plasticity around 400 to $550^{\circ} \mathrm{C}$. Low-rank coals such as brown coals and subbituminous coals, on the other hand, have no thermal plasticity upon being heated in inert gas atmosphere, suggesting a lack of the low-molecular-weight compounds. This is partly because so-called cross-linking reactions or polymerization reactions take place below $400^{\circ} \mathrm{C}$ at hydrogen bondings forming between oxygencontaining functional groups such as hydroxyl groups and carboxyl groups. ${ }^{7-9)}$ The cross-linking reactions are more significant for lower-rank coals such as brown coals.

In this study we propose to pretreat low-rank coals in non-polar solvent below $400^{\circ} \mathrm{C}$ for converting them to a substitute for coking coals. In the proposed method, it is expected that the solvent breaks the hydrogen bondings which are thermally weakened above $140{ }^{\circ} \mathrm{C}^{10)}$ and pulls the molecules apart by dissolving them to suppress the crosslinking reactions while decomposing oxygen-containing

* Corresponding author: E-mail: ashida@cheme.kyoto-u.ac.jp DOI: http://dx.doi.org/10.2355/isijinternational.ISIJINT-2016-276 functional groups. Non-polar solvent was chosen in the proposed method because polar solvents which are strongly associated with coal molecules are difficult to be recovered from the product.

We have recently shown that the treatment of lowrank coals or biomass wastes in non-polar solvent such as 1-methylnaphthalene at around $350^{\circ} \mathrm{C}$ can produce a significant amount of low-molecular-weight compounds whose elemental compositions were comparable to that of bituminous coal. ${ }^{1-13)}$ In this study we first validated the concept of increasing the low-molecular-weight compounds by the proposed method and then examined the possibility of the solvent-treated coal as a raw material in coke making process.

\section{Experimental}

\subsection{Samples}

An Australian brown coal, Loy Yang coal, and an Indonesian subbituminous coal, Adaro coal, were used in this study. The properties of the coals used were shown in Table 1. 1-methylnaphthalene (Merck) was used as the solvent.

Table 1. Properties of the low-rank coals used in this study.

\begin{tabular}{|c|c|c|c|c|c|c|c|}
\hline \multirow{2}{*}{ Sample } & \multicolumn{4}{|c|}{ Ultimate analysis [wt\%, d.a.f.] } & \multicolumn{2}{|c|}{$\begin{array}{c}\text { Atomic ratio } \\
{[-]}\end{array}$} & \multirow{2}{*}{$\begin{array}{c}\text { Ash } \\
{[\mathrm{wt} \%, \mathrm{~d} . \mathrm{b} .]}\end{array}$} \\
\hline & $\mathrm{C}$ & $\mathrm{H}$ & $\mathrm{N}$ & $\begin{array}{l}\mathrm{O}+\mathrm{S} \\
\text { (diff.) }\end{array}$ & $\mathrm{H} / \mathrm{C}$ & $\mathrm{O} / \mathrm{C}$ & \\
\hline $\begin{array}{l}\text { Loy } \\
\text { Yang }\end{array}$ & 69.1 & 3.8 & 0.7 & 26.4 & 0.66 & 0.29 & 1.5 \\
\hline Adaro & 70.0 & 5.2 & 1.7 & 23.1 & 0.89 & 0.25 & 2.7 \\
\hline
\end{tabular}




\subsection{Solvent Treatment}

The coal and solvent at different mixing ratios were charged in a small autoclave (ca. $12 \mathrm{~cm}^{3}$ ) made of stainless steel. After purging the inside of the autoclave with nitrogen gas, the autoclave was heated at $5 \mathrm{~K} / \mathrm{min}$ up to $350^{\circ} \mathrm{C}$ or $400^{\circ} \mathrm{C}$, at which it was kept for $1 \mathrm{~h}$. Final autogenic pressure was 2 to $4 \mathrm{MPa}$. The solvent was evaporated at $140^{\circ} \mathrm{C}$ under reduced pressure to obtain solvent-treated coals (STC).

\subsection{Fractionation of the Treated Coals}

In order to quantify the amount of low-molecular-weight compounds in STCs, the STCs were extracted by 1-methylnaphthalene at $350^{\circ} \mathrm{C}$ using a flow-type extractor. ${ }^{14,15)}$ The extraction separated the STC into residue (Residue), the solid extract that precipitated from the extract at room temperature (Deposit), and the extract soluble in solvent even at room temperature (Soluble). Molecular weight of the Soluble should be the lowest and that of the Residue should be the highest among the three fractions.

\subsection{Analyses of the Treated Coals}

Ultimate analyses of the STCs were performed using a CHN analyzer (Yanaco, MT-6). Melting and plastic behaviors of the Solubles were examined using a thermomechanical analyzer (Shimadzu; TMA50) in which the displacement depth of a rod into a solid sample bed was continuously monitored while heating the sample at $10 \mathrm{~K} / \mathrm{min}$ in a nitrogen flow. In the thermomechanical analysis, a sample was placed in a pan (5.2 $\mathrm{mm}$ I.D. and $6.0 \mathrm{~mm}$ high) at the height of $1 \mathrm{~mm}$ and the rod of $4.3 \mathrm{~mm}$ in diameter was loaded with a constant load of $0.098 \mathrm{~N}$.

\subsection{Coke Preparation and Evaluation}

Four coking coals shown in Table 2 were used for coke preparation. A, B, C coals are strongly-coking coals whereas $\mathrm{D}$ coal is a slightly-coking coal. Each coal was pulverized to less than $1 \mathrm{~mm}$ in diameter. Table 3 shows the mixing ratios of the coals for preparing cokes. The coking coals were

Table 3. Mixing ratios of the coals for preparing cokes ( $\mathrm{wt} \%$ d.b.).

\begin{tabular}{cccccccc}
\hline \multirow{2}{*}{ Abbreviation } & A & B & C & D & \multicolumn{3}{c}{ Loy Yang or Adaro } \\
\cline { 5 - 8 } & & & & & Raw & $\mathrm{N}_{2}$ & STC \\
\hline Base & 40 & 5 & 5 & 50 & 0 & 0 & 0 \\
Raw & 40 & 5 & 5 & 45 & 5 & 0 & 0 \\
$\mathrm{~N}_{2}$ & 40 & 5 & 5 & 45 & 0 & 5 & 0 \\
STC & 40 & 5 & 5 & 45 & 0 & 0 & 5 \\
\hline
\end{tabular}

mixed with the raw low-rank coals, the $\mathrm{N}_{2}$-treated low-rank coals (solvent-to-coal ratio $=0$ ), or STCs.

Figure 1 shows a schematic of the mold used for coke preparation. $2 \mathrm{~g}$ of the mixed coals were placed in a stainless steel tube (I.D.: $17.0 \mathrm{~mm}$ ) between two stainless steel cylinders (Diameter: $16.8 \mathrm{~mm}$, Height: $20.0 \mathrm{~mm}$ ). The mold was heated in a nitrogen atmosphere at a rate of $3 \mathrm{~K} / \mathrm{min}$ up to $900^{\circ} \mathrm{C}$ where it was kept for $30 \mathrm{~min}$. The evolved gas can get out of the mold through a small gap between the tube and cylinders.

Prepared cokes were served to a compressive strength test as well as observation under crossed nicols using a polarization microscope.

\section{Results and Discussion}

\subsection{Upgrading Behavior in Solvent Treatment}

Figure 2 shows the effect of solvent-to-coal ratio on the yields of gaseous products and fractions constituting STC (or $\mathrm{N}_{2}$-treated coal for solvent-to-coal ratio $=0$ ) for Loy Yang coal. The yield of STC is a sum of the Residue, Deposit, and Soluble yields and is shown with thick lines in

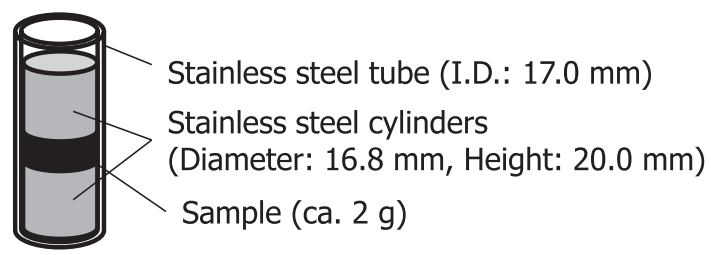

Fig. 1. A schematic of the mold used for coke preparation.

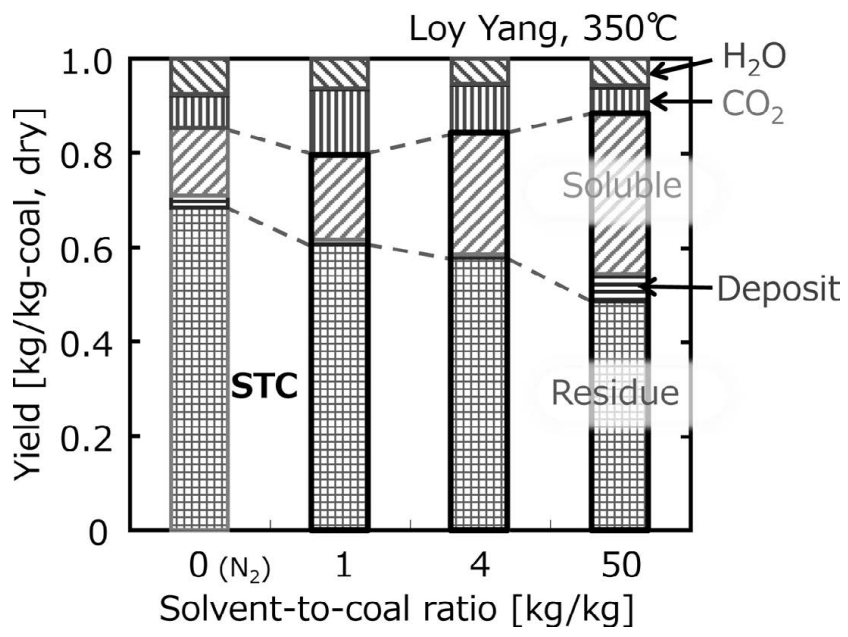

Fig. 2. Effect of solvent-to-coal ratio on the yields of gaseous products and fractions constituting STC (or $\mathrm{N}_{2}$-treated coal for solvent-to-coal ratio $=0$ ) for Loy Yang coal.

Table 2. Properties of the coking coals used in this study.

\begin{tabular}{|c|c|c|c|c|c|c|c|c|c|c|}
\hline \multirow[t]{2}{*}{ Sample } & \multicolumn{5}{|c|}{ Ultimate analysis [wt $\%$, d.a.f.] } & \multicolumn{2}{|c|}{ Atomic ratio $[-]$} & \multicolumn{2}{|c|}{$\begin{array}{c}\text { Proximate analysis } \\
\text { [wt } \%, \text { d.b. }]\end{array}$} & \multirow{2}{*}{$\underset{[-]}{\log M F}$} \\
\hline & $\mathrm{C}$ & $\mathrm{H}$ & $\mathrm{N}$ & $\mathrm{S}$ & $\mathrm{O}$ (diff.) & $\mathrm{H} / \mathrm{C}$ & $\mathrm{O} / \mathrm{C}$ & Ash & VM & \\
\hline A & 90.5 & 4.6 & 1.4 & 0.4 & 3.1 & 0.61 & 0.03 & 9.6 & 23.0 & 1.50 \\
\hline B & 90.2 & 4.6 & 2.0 & 0.6 & 2.6 & 0.62 & 0.02 & 10.3 & 21.2 & 2.02 \\
\hline $\mathrm{C}$ & 89.6 & 4.7 & 1.6 & 0.3 & 3.8 & 0.63 & 0.03 & 10.5 & 21.8 & 1.82 \\
\hline $\mathrm{D}$ & 83.4 & 5.5 & 2.0 & 0.5 & 8.6 & 0.79 & 0.08 & 7.5 & 35.9 & 1.11 \\
\hline
\end{tabular}


the figure. The yield of STC ranged from 0.80 to $0.88 \mathrm{~kg} /$ kg-dry raw coal. $\mathrm{CO}_{2}$ and $\mathrm{H}_{2} \mathrm{O}$ were formed at any solventto-coal ratio, suggesting that deoxygenation reactions took place during the treatment. A larger amount of low-molecular weight compounds or the Soluble formed in the presence of the solvent than in the absence of the solvent, suggesting the validity of the proposed method. The STC became more abundant in the Soluble with increasing the solvent-to-coal ratio, reaching as large as $0.38 \mathrm{~kg} / \mathrm{kg}$-STC $(0.34 \mathrm{~kg} / \mathrm{kg}$-dry raw coal). It can be expected that the abundance of the Soluble should contribute to improving caking property of the low-rank coals.

Table 4 shows elemental compositions of STCs or $\mathrm{N}_{2}$-treated coals prepared from Loy Yang coal at different solvent-to-coal ratios and temperatures. Carbon contents of the STCs were all over 79\%-d.a.f., which was comparable to those of bituminous coals. Figure 3 shows elemental compositions of STCs, $\mathrm{N}_{2}$-treated coals, and raw coal on $\mathrm{H} / \mathrm{C}$ vs $\mathrm{O} / \mathrm{C}$ diagram for Loy Yang coal. The $\mathrm{O} / \mathrm{C}$ values of STCs were reduced to less than half of that for the raw coal. The $\mathrm{O} / \mathrm{C}$ values of STCs prepared at $400^{\circ} \mathrm{C}$ were reduced down to smaller than 0.10 , which was comparable to that of the slightly-coking coal, D. The STCs had a little smaller $\mathrm{O} / \mathrm{C}$ values than $\mathrm{N}_{2}$-treated coals (solvent-to-coal ratio $=0$ ). Although the $\mathrm{H} / \mathrm{C}$ value did not change significantly through the treatment, the $\mathrm{H} / \mathrm{C}$ values of STCs prepared at $400^{\circ} \mathrm{C}$ were a little smaller than that of STCs prepared at $350^{\circ} \mathrm{C}$.

These results indicate that the treatment in 1-methylnaphthalene solvent can deoxygenate low-rank coals significantly while suppressing cross-linking or polymerization reactions which often accompany deoxygenation reactions. Instead of the cross-linking reactions, deoxygenation reactions within a single molecule should take place such as dehydration reactions of alcoholic hydroxyl groups within a molecule to form $\mathrm{C}=\mathrm{C}$ bonds.

\subsection{Possibility of STC as a Raw Material for Coke}

Figure 4 compares relative abundance of the Soluble, Deposit, and Residue for $\mathrm{N}_{2}$-treated coal (solvent-to-coal ratio $=0$ ), and STC (solvent-to-coal ratio $=50$ ) prepared from Loy Yang coal at $400^{\circ} \mathrm{C}$ as well as for the four coking coals. The lower-molecular-weight fractions, Soluble and Deposit, accounted for $0.32-0.36 \mathrm{~kg} / \mathrm{kg}$-d.b. of the coking coals. On the other hand, the $\mathrm{N}_{2}$-treated coal had as small as $0.20 \mathrm{~kg} / \mathrm{kg}$-d.b. of Soluble and Deposit. The STC had as large as $0.32 \mathrm{~kg} / \mathrm{kg}$-d.b. of Soluble and Deposit although its Deposit fraction was less than those of the coking coals.

Figure 5 shows thermomechanical analysis curves for
Solubles of the STCs prepared from Loy Yang coal and the coking coals. When the sample melts completely in this analysis, the rod displaces the sample and reaches the bottom of the sample pan, which corresponds to the normalized displacement value, -1.0 . All the Solubles can be judged to have melted completely. The Solubles of the STCs melted at around $100^{\circ} \mathrm{C}$, a little lower temperature than those of the coking coals.

It was thus shown that the solvent treatment can increase the ratio of low-molecular-weight compounds, whose softening and melting behavior are similar to those of coking coals, up to the ratio of low-molecular-weight compounds

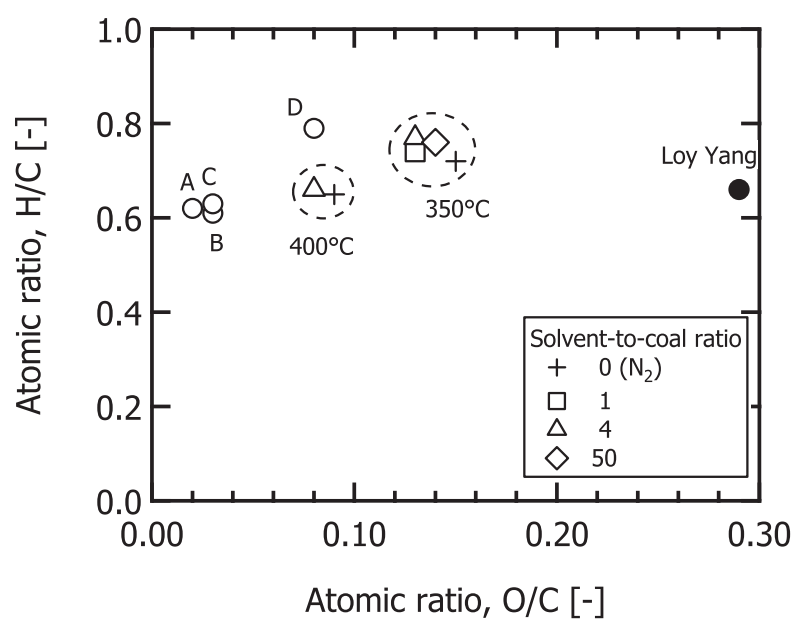

Fig. 3. Elemental compositions of STCs, $\mathrm{N}_{2}$-treated coals, and raw coal on $\mathrm{H} / \mathrm{C}$ vs $\mathrm{O} / \mathrm{C}$ diagram for Loy Yang coal.

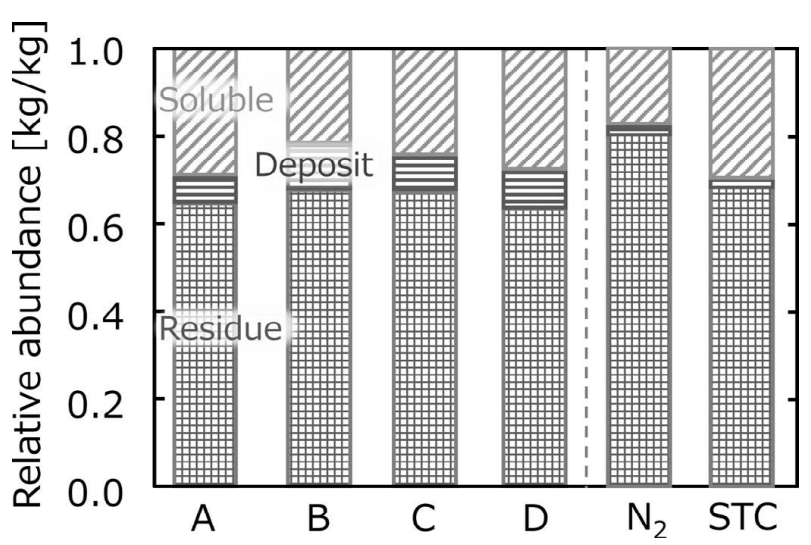

Fig. 4. Relative abundance of the Soluble, Deposit, and Residue for $\mathrm{N}_{2}$-treated coal, STC (solvent-to-coal ratio $=50$ ) prepared from Loy Yang coal at $400^{\circ} \mathrm{C}$, and the coking coals.

Table 4. Elemental compositions of STCs or $\mathrm{N}_{2}$-treated coals prepared from Loy Yang coal.

\begin{tabular}{|c|c|c|c|c|c|c|c|c|}
\hline \multirow{2}{*}{$\begin{array}{l}\text { Solvent-to-coal } \\
\quad \text { ratio }[-]\end{array}$} & \multirow{2}{*}{$\begin{array}{l}\text { Treatment } \\
\text { temperature }\end{array}$} & \multicolumn{4}{|c|}{ Ultimate analysis $[\mathrm{wt} \%$, d.a.f.] } & \multicolumn{2}{|c|}{ Atomic ratio $[-]$} & \multirow{2}{*}{$\begin{array}{c}\text { Ash } \\
{[\mathrm{wt} \% \text {, d.b. }}\end{array}$} \\
\hline & & $\mathrm{C}$ & $\mathrm{H}$ & $\mathrm{N}$ & $\mathrm{O}+\mathrm{S}$ (diff.) & $\mathrm{H} / \mathrm{C}$ & $\mathrm{O} / \mathrm{C}$ & \\
\hline $0\left(\mathrm{~N}_{2}\right)$ & 350 & 78.8 & 4.7 & 0.9 & 15.6 & 0.72 & 0.15 & 2.1 \\
\hline 1 & 350 & 80.6 & 5.0 & 0.9 & 13.5 & 0.74 & 0.13 & 2.6 \\
\hline 4 & 350 & 79.9 & 5.1 & 0.8 & 14.2 & 0.77 & 0.13 & 2.0 \\
\hline 50 & 350 & 79.1 & 5.0 & 0.9 & 15.0 & 0.76 & 0.14 & 2.3 \\
\hline $0\left(\mathrm{~N}_{2}\right)$ & 400 & 84.3 & 4.6 & 1.0 & 10.1 & 0.65 & 0.09 & 2.1 \\
\hline 4 & 400 & 85.7 & 4.7 & 1.0 & 8.6 & 0.66 & 0.08 & 2.4 \\
\hline
\end{tabular}




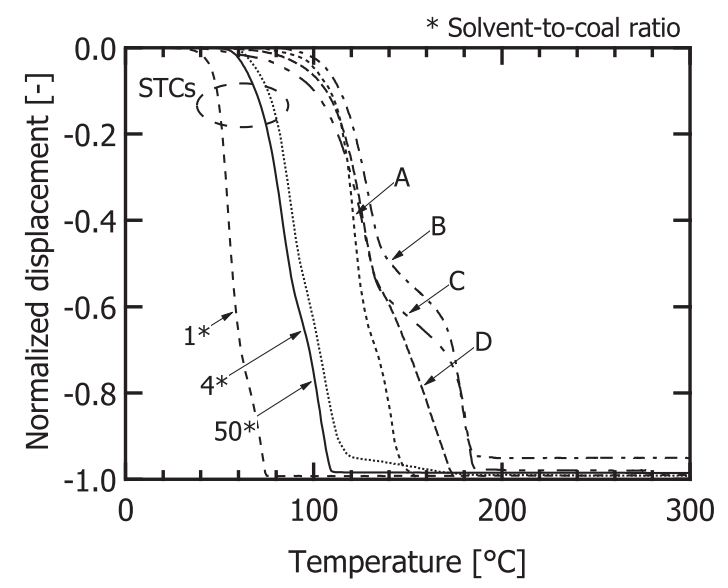

Fig. 5. Thermomechanical analysis curves for Solubles of the STCs prepared from Loy Yang coal and the coking coals.

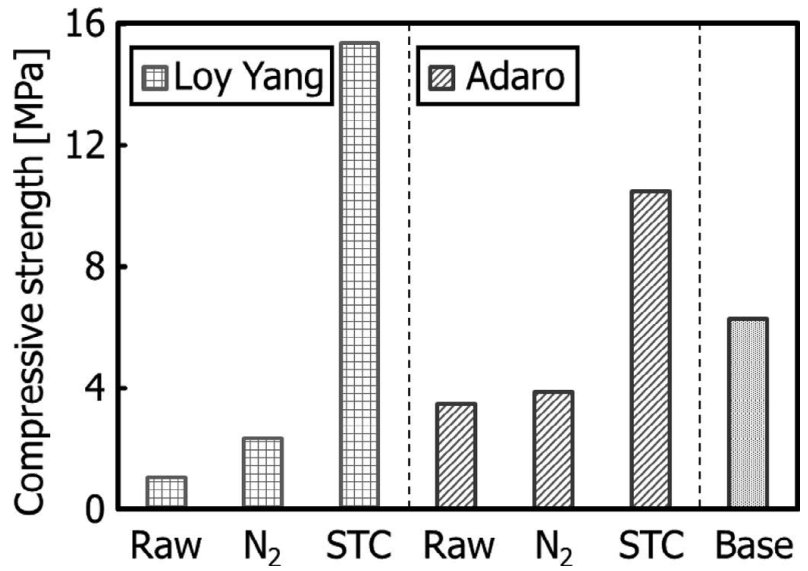

Fig. 6. Compressive strengths of the cokes prepared.

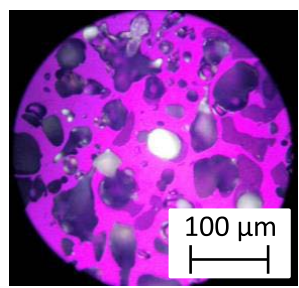

Raw

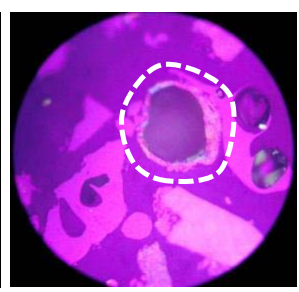

$\mathrm{N}_{2}$

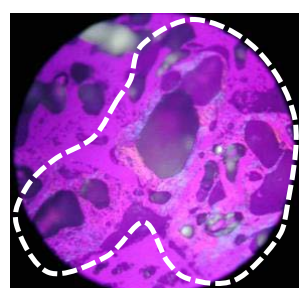

STC

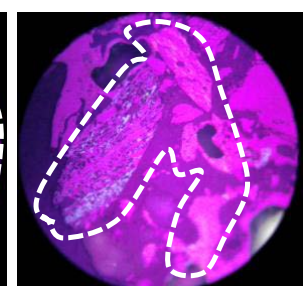

Base

Fig. 7. Polarization microscope images of cokes prepared (anisotropic textures are seen inside the broken lines) (Online version in color.)

in coking coals.

Then, the possibility of STC as a raw material for metallurgical coke was examined. The STC itself did not have distinct thermal plasticity, which may be due to the lack of Deposit fraction. So, the possibility of STC as a substitute for a slightly-coking coal was examined. Coke prepared from a mixture of $50 \mathrm{wt} \%$ strongly-coking coals (A, B, and $\mathrm{C}$ coals) and $50 \mathrm{wt} \%$ slightly-coking coal (D coal), abbreviated to Base, was compared with the coke prepared from a mixture of $50 \mathrm{wt} \%$ of the same strongly-coking coals, 45 wt $\%$ of the same slightly-coking coal, and $5 \mathrm{wt} \%$ of STC (prepared at $400^{\circ} \mathrm{C}$ ) as the mixing ratios of the coals are shown in Table 3. Raw low-rank coals or the $\mathrm{N}_{2}$-treated coals were also used in the same way by substituting for 5 wt $\%$ of the slightly-coking coal. Compressive strengths of the cokes were compared in Fig. 6. When using raw coals or $\mathrm{N}_{2}$-treated coals even by $5 \mathrm{wt} \%$, the strength decreased dramatically from that of the Base coke. When using STC, however, much stronger cokes than the Base cokes as well as the cokes prepared using raw coals or $\mathrm{N}_{2}$-treated coals were obtained, suggesting the possibility of STC as a raw material for coke making.

Figure 7 compares polarization microscope images of the cokes prepared. A large amount of anisotropic texture was observed in the Base coke and the coke prepared using STC whereas much less anisotropic texture was found in the cokes prepared using raw coal or $\mathrm{N}_{2}$-treated coal. This result shows that STC did not prevent anisotropic texture of coking coals from developing, which should be one of the reasons why the coke prepared using STC was of high strength.

\section{Conclusions}

Treatment in non-polar solvent at $350^{\circ} \mathrm{C}$ to $400^{\circ} \mathrm{C}$ was found to be effective in converting low-rank coals such as brown coals and subbituminous coals into upgraded coals having a large carbon content and a large amount of lowmolecular-weight compounds. The possibility of the solvent treated coal (STC) as a raw material for coke making was shown.

\section{REFERENCES}

1) T. Shimmura: Fuel, 12 (1933), 204

2) H. R. Brown and P. L. Waters: Fuel, 45 (1966), 17.

3) K. Ouchi, K. Tanimoto, M. Makabe and H. Itoh: Fuel, 62 (1983), 1227.

4) D. W. van Krevelen, F. J. Huntjens and H. N. M. Dormans: Fuel, 35 (1956), 462.

5) H. A. G. Chermin and D. W. van Krevelen: Fuel, 36 (1957), 85.

6) I. G. C. Dryden and W. K. Joy: Fuel, 40 (1961), 473.

7) E. M. Suuberg, D. Lee and J. W. Larsen: Fuel, 64 (1985), 1668.

8) P. R. Solomon, M. A. Serio, G. V. Despande and E. Kroo: Energy Fuel., 4 (1990), 42.

9) J. V. Ibarra, I. Cervero, M. Garcia and R. Moliner: Fuel Process. Technol., 24 (1990), 19.

10) K. Miura, K. Mae, W. Li, T. Kusakawa, F. Morozumi and A. Kumano: Energy Fuel., 15 (2001), 599.

11) R. Ashida, S. Umemoto, Y. Hasegawa, K. Miura, K. Kato, K. Saito and S. Nomura: Proc. 26th Annual Int. Pittsburgh Coal Conf., University of Pittsburgh, Pittsburgh, PA, (2009), Paper No. 5-1.

12) J. Wannapeera, X. Li, N. Worasuwannarak, R. Ashida and K. Miura: Energy Fuel., 26 (2012), 4521.

13) X. Li, R. Ashida and K. Miura: Energy Fuel., 26 (2012), 6897.

14) K. Miura, K. Mae, H. Shindo, R. Ashida and T. Ihara: J. Chem. Eng. Jpn., 36 (2003), 742.

15) R. Ashida, K. Nakagawa, M. Oga, H. Nakagawa and K. Miura: Fuel, 87 (2008), 576. 